\title{
A Comparative Study of Virus Haemagglutinins. The Stability of Haemagglutinins and Red Cell Receptors to Gertain Physical and Ghemical Treatments
}

\author{
By F. E. BUCKLAND and D. A. J. TYRRELL \\ National Institute for Medical Research, Common Cold Research Unit, \\ Harvard Hospital, Salisbury, Wiltshire
}

(Received 3 January 1963)

\begin{abstract}
SUMMARY
A study of 22 haemagglutinating viruses was made to see whether by treating the viruses and the receptors on the red cells with a variety of physical and chemical agents, a convenient means could be devised for identifying and classifying these viruses, while throwing some light on the chemical basis of the haemagglutination reaction. The viruses were submitted to 13 different treatments; acid, urea, $p$-chloromercuribenzoic acid, deoxycholate and possibly bisulphite might be useful for the classification of unknown agents since they gave similar results with all members of a biological group. Other treatments (e.g. formaldehyde) gave results which varied from strain to strain in such a group of viruses and might be useful for genetic studies. The red cells were treated in nine different ways; formalin, papain, chymotrypsin, periodate, receptordestroying enzyme, $(\mathrm{RDE})$ and swine influenza virus each prevented agglutination by one or two viruses (apparently by inactivating cell receptors). These results were complementary to those with the virus haemagglutinins. The importance of standardized conditions of test are emphasized.
\end{abstract}

\section{INTRODUCTION}

It is known that viruses belonging to many biological groups can agglutinate red cells, and that this is usually a property of the virus particle. The haemagglutinins of vaccinia and the psittacosis group can be separated from the particle itself, but in the work reported here only viruses in which the haemagglutinin and virus particle are closely associated were used. We wished to obtain by simple in vitro tests some basic information on the constitution of various viruses. The inactivation of receptors by neuraminidase provided a useful criterion for identifying members of the myxovirus group (Andrewes, Bang \& Burnet, 1955). It seemed likely that if a variety of agents were used on the haemagglutinins and the red cell receptors of a variety of viruses the results would fall into a pattern which might provide a rapid method of classifying and identifying haemagglutinating viruses.

\section{METHODS}

Table 1 shows the viruses that were used and outlines their preparation in chick embryos, mice and tissue culture. In tests on the viral haemagglutinin it was necessary to prepare the viruses in a non-inhibitory suspension since, for instance, allantoic fluid contains a strong trypsin inhibitor. Therefore, myxoviruses in allantoic 
fluid were purified by adsorption on to, and elution from, red cells, or were grown in media containing lactalbumin hydrolysate (LAH) and yeast extract (YE) but no serum; the latter medium was used for ECHO and REO viruses also.

Table 1. Viruses used, their preparation and the species of red cells used in haemagglutination tests

All culture media were based on Hanks' saline and contained $0.1 \%$ sodium bicarbonate and 100 units penicillin/ml., 50 units mycostatin $/ \mathrm{ml}$. and $100 \mu \mathrm{g}$. streptomycin/ ml. $0.5 \%$ red cells used with GD VII; otherwise $1 \%$. Test at $4{ }^{\circ}$ with EMC group and GD VII; otherwise at room temperature.

Virus group Myxovirus

Type and strain
Influenza A WS
Influenza A Mel
Influenza A2
A/Eng/59
Influenza A2
Iksha
Influenza B Lee
Parainfluenza I
Sendai
Mumps

\section{REO virus Type I}

Type 2

ECHO virus Type 7
Type 11 prototype
Type $11 \mathrm{U}$
Type 12

Theiler's Type 12

mouse ence-

\section{GD VII}

phalitis virus

$\begin{array}{clc}\begin{array}{c}\text { Encephalo } \\ \text { myocar- } \\ \text { ditis virus }\end{array} & \text { EMC } & \begin{array}{c}\text { Mouse ascites } \\ \text { tumour cells }\end{array} \\ \begin{array}{c}\text { Adenovirus } \\ \text { Adeno 7 prototype }\end{array} & \text { HeLa cells } \\ & \text { Adeno 9 prototype } & \text { HeLa cells } \\ & \text { SV 17 } & \text { Mouse kidney }\end{array}$

$\begin{array}{ll}\begin{array}{l}\text { Arthropod- } \\ \text { borne }\end{array} & \text { A. Semliki Forest } \\ \text { virus } & \text { B. West Nile } \\ \begin{array}{c}\text { Pneumonia } \\ \text { virus of }\end{array} & \text { PVM } \\ \text { mice } & \end{array}$

Chick embryo allantois

Chick embryo allantois

Calf kidney

Calf kidney:

chick embryo

allantois

Chick embryo

amnion and allantois lung

Mouse

Mouse
Culture media and purification, if any

Red cells
$0 \cdot 1 \%$ yeast extract, Human $0.5 \%$ LAH $^{*}$ or $5 \%$ horse serum, Human $\mathbf{0 . 2 5} \%$ LAH

Monkey kidney

Monkey kidney

Human embryo

Monkey kidney

Monkey kidney

Monkey kidney

As for WS and Mel
-

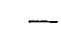

As for WS and Mel

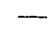

Human and sheep

Human and sheep

Human

Human and sheep

Human and sheep

199 (Parker), also Human

$0.1 \%$ yeast extract

$0.5 \%$ LAH

$1 \%$ or $2 \%$ calf serum, $\mathbf{0} \cdot 25 \%$ LAH

$2 \%$ calf serum, $0.25 \%$ LAH or

$0.5 \%$ LAH, $0.1 \%$ yeast extract

Arcton treated brain Human Human

$\begin{array}{cl}\begin{array}{c}\text { Supernatant fluid } \dagger \\ \text { Arcton-treated brain }\end{array} & \begin{array}{l}\text { Sheep } \\ \text { Sheep }\end{array} \\ & \\ 5 \% \text { rabbit serum, } & \text { Rhesus monkey } \\ 0.25 \% \text { LAH } & \\ 5 \% \text { rabbit serum, } & \text { Human } \\ \mathbf{0 . 2 5} \% \text { LAH } & \\ \mathbf{1 9 9} \text { (Parker) or } 2 \% & \text { Human } \\ \text { calf serum, 0.25\% } & \\ \text { LAH } & \\ \text { Arcton-treated brain } & \text { Goose } \\ \text { Arcton-treated brain } & \text { Goose } \\ & \\ \text { Arcton-treated lung } & \text { Mouse }\end{array}$

Arcton-treated lung
Suckling mouse Suckling mouse

* Lactalbumin hydrolysate. † Martin, Malec, Sved \& Work (1961) 
Adenovirus suspensions were prepared from the cells only and purified by extraction with trifluorotrichloroethane ('Arcton' 113: Imperial Chemical Industries Ltd.) All these virus suspensions had no inhibitory action on proteolysis of gelatin by trypsin.

In tests on the red cell receptors untreated culture fluids were used except in the case of REO and adenoviruses where the cells were disintegrated in the medium by a mechanical blendor.

Saline. Except where stated otherwise, phosphate buffered saline (PBS) was used, i.e. $0 \cdot 14 \mathrm{~m}$-sodium chloride $+\mathbf{0} \cdot 01 \mathrm{~m}$-phosphate buffer at $\mathrm{pH} \mathbf{7 \cdot 2}$.

Red cells. These were taken with sterile precautions, stored in glucose + gelatin + veronal solution (Clarke \& Casals, 1958). Human group O cells from one donor were used but rhesus monkey cells were used for adenovirus type 7, sheep cells for encephalomyocarditis virus (EMC), goose cells for arthropod-borne viruses, and mouse cells for pneumonia virus of mice (PVM).

\section{Treatment of viruses}

Urea. Dilutions from 1 to $8 \mathrm{M}$ were mixed with equal volumes of virus and incubated for $1 \mathrm{hr}$. at $37^{\circ}$ and dialysed at $4^{\circ}$ against PBS for $3 \mathrm{hr}$.

$\mathrm{pH}$ values. $\mathrm{m}$-buffers were made with a range from $\mathrm{pH} 2$ to $\mathrm{pH} 10 ; \mathrm{pH} 2,3$ and 4 were citrate, $\mathrm{pH} 5$ acetate, $\mathrm{pH} 6,7$ and 8 phosphate, $\mathrm{pH} 9$ and 10 glycine buffers. Equal volumes of virus and buffer were mixed for $1 \mathrm{hr}$. at room temperature, then dialysed against PBS for $3 \mathrm{hr}$. at $4^{\circ}$.

Heat. Separate samples were kept in $56^{\circ}$ water bath for $20,40,60 \mathrm{~min}$.; in the $37^{\circ}$ bath for 1,3 and $16 \mathrm{hr}$.

Ether. Four volumes of virus +1 volume of ether were held at $4^{\circ}$ overnight. The ether layer was pipetted off.

Formalin (formaldehyde solution $40 \%$, w/v). Virus was mixed with an equal volume of $20 \%$ formalin in PBS, left at $4{ }^{\circ}$ overnight and then dialysed for $2 \mathrm{hr}$. at 4 .

Periodate. Equal volumes of virus suspension and $0 \cdot 046 \mathrm{M}$-sodium metaperiodate were mixed and held at room temperature for $1 \mathrm{hr}$. and then dialysed against PBS for $3 \mathrm{hr}$.

Bisulphite. As for periodate, but with $0 \cdot 104 \mathrm{M}-\mathrm{Na}_{2} \mathrm{~S}_{2} \mathrm{O}_{5}$ and subsequently with $0.052 \mathrm{M}, 0.026 \mathrm{M}$ and $0.013 \mathrm{M}$ solutions.

Enzymes. Trypsin and chymotrypsin were prepared by dissolving $0 \cdot 1$ g. crystalline material in $10 \mathrm{ml} .0 .01 \mathrm{~N}-\mathrm{HCl}$. This stock solution was kept frozen and diluted 1/100 with 2-amino-2-hydroxymethylpropane-1,3-diol (tris) buffer ( $\mathrm{pH} \mathrm{7 \cdot 6)}$ before use. Equal parts of enzyme solution and of virus were held for $2 \mathrm{hr}$. at $37^{\circ}$. The control in tris buffer was similarly treated.

Papain. This was prepared according to the method of Muschel \& Piper (1959); $2 \mathrm{~g}$. crude papain in $10 \mathrm{ml} .0 .05 \mathrm{~N}-\mathrm{HCl}$ was diluted in tris buffer with ethylene diamine tetra-acetic acid (EDTA; $0.001 \mathrm{M})$ and cysteine $0.001 \mathrm{M}(\mathrm{pH} 7 \cdot 1)$ to $1 \%$ papain.

Thiol reagents: see Buckland (1960).

Sodium deoxycholate. Virus was mixed with an equal volume of $0.0048 \mathrm{M}$-sodium deoxycholate, incubated at $37^{\circ}$ for $\mathrm{I} \mathrm{hr}$. and then dialysed overnight against 0.01 M-PBS. 


\section{Treatment and method of use of red cells}

The red cells were usually suspended in the reagent dissolved in saline and shaken by hand at intervals. Thereafter the cells were centrifuged ( $500 \mathrm{~g}$. for $5 \mathrm{~min}$.), resuspended in saline and used immediately or after a short time at $4^{\circ}$. Table 2 shows the concentrations of reagents and red cells used and other details of the treatments. The mouse red cells used for PVM did not withstand these treatments; consequently only the haemagglutinin was investigated.

\section{Table 2. Treatment of red cells}

Proteolytic enzymes were assayed frequently Two-fold dilutions were made in Hanks' saline containing $5 \%$ sodium bicarbonate. To $1.25 \mathrm{ml}$. of each dilution $0.5 \mathrm{ml}$. of $7.5 \%$ gelatine were added. They were incubated at $37^{\circ}$ for $1 \mathrm{hr}$. and failure to set on cooling was taken as the end-point.

\section{Reagent}

Formalin (formaldehyde solution $40 \%, \mathrm{w} / \mathrm{v})$

Sodium metaperiodate

Sodium metabisulphite

Papain (BDH) titre 13,000

Trypsin (crystalline, Difco) titre $8000-64,000$

Chymotrypsin (Armour) titre $\mathbf{4 0 0 0}$

$p$-Chloromercuribenzoic acid

Iodoacetamide

Cholera filtrate

(N.V. Philips-Roxane (Duphar))

\section{Quantities used}

1 vol. packed cells and $3 \cdot 4$ vol. of $1 \%$ formalin

*(a) 1 vol. of $10 \%$ cell suspension and 9 vol. $0 \cdot 0058 \mathrm{M}-\mathrm{NaIO}_{4}$

(b) 1 vol. of $10 \%$ red cells, 1 vol. of $\mathrm{NaIO}_{4}$ at dilution ranges $0.0016 \mathrm{M}$ to $0.0008 \mathrm{M}$

1 vol. of $10 \%$ cell suspension and 9 vol. of $0.026 \mathrm{M}-\mathrm{Na}_{2} \mathrm{~S}_{2} \mathrm{O}_{5}$

Stock prepared according to Muschel \& Piper (1959), 5 vol. of $2 \%$ papain and 1 vol. packed cells

Stock $0.1 \%$ in $0.01 \mathrm{~N}-\mathrm{HCl}, 1$ vol. of $0.01 \%$ trypsin and 1 vol. packed cells

As for trypsin

$10^{-3} \mathrm{M}$ or $10^{-4} \mathrm{M}$ dilution mixed with equal volume $10 \%$ cells

$10^{-3} \mathrm{M}$ or $10^{-4} \mathrm{M}$ dilution mixed with equal volume $10 \%$ cells

Reconstituted: diluted in saline. Serial dilutions mixed with $5 \%$ packed cells
Temperature and time of treatment

$37^{\circ}$, overnight

Room temperature;

$1 \mathrm{hr}$.

$4^{\circ} ; 1 \mathrm{hr}$.

Room temperature;

$1 \mathrm{hr}$.

$37^{\circ}$; $30 \mathrm{~min}$.

$37^{\circ}$; overnight

As for trypsin

Room temperature;

$1 \mathrm{hr}$.

Room temperature;

$1 \mathrm{hr}$;

$37^{\circ} ; 2-5 \mathrm{hr}$.

* In method $(a)$ with ambient temperature $15-20^{\circ}$ the experiment was carried out on the bench. In method $(b)$ with ambient temperature $21-26^{\circ}$ to avoid haemolysis the treatment of red cells was carried out at $4^{\circ}$, the test set up on the bench, but subsequently allowed to settle at $4^{\circ}$.

\section{Haemagglutination tests}

Haemagglutination tests were usually carried out at room temperature in plastic plates. Serial two-fold dilutions of virus were made in saline and an equal volume $(0.25 \mathrm{ml}$.) of $1 \%$ red cell suspension was added to each cup. The test was read by observing the pattern of sedimentation, and partial agglutination was taken as the end-point. Glass test tubes were used in titrations of GD VII virus as, otherwise, 
clear patterns were not obtained. Other variations in technique are given in Table 1. It was found that non-specific inhibitors for SV 17 and arthropod-borne viruses, derived from tissues, were removed by treatment in a mechanical blendor with Arcton 113.

\section{Assessment of results}

An attempt was made to obtain quantitative results with each reagent. Viruses or red cells were treated with various dilutions. The difference in titre from that of the controls was called the 'titre reduction' and plotted or tabulated. A reduction of four-fold was taken as significant in a single test; an average reduction of less than four-fold was sometimes significant in repeated tests (see Table 4). When a difference was not precisely known because an end-point was not reached it was assumed for purposes of calculation that the end-point lay at the next step in the dilution series, e.g. a titre reduction from 64 to $<4$ was treated as a reduction of 64 to 2. The concentrations of reagents tested usually ranged from the maximum that could be used without producing obvious signs of damage to the red cells, (e.g. haemolysis or spontaneous agglutination), to the lowest concentration which produced any effect with the most sensitive virus. In most instances, this was a narrow range, but with periodate and cholera filtrate various dilutions were studied. All the results reported here are based on tests repeated several times, usually with different batches of virus, red cells and reagents.

\section{RESULTS}

\section{Treatment of haemagglutinins}

The haemagglutinins of most viruses were impaired or destroyed by a variety of reagents, but there were significant differences in the types of reagents which were active and the concentrations at which they were effective on different viruses.

$\mathrm{pH}$ range. Some typical results are shown in Fig. 1; it may be seen that the haemagglutinins were mostly stable in alkaline conditions and that there was a sharply defined transition from no effect to a marked one over a $\mathrm{pH}$ range of 1 to 2 units. These results held good for other viruses in the same biological group.

PVM and ECHO viruses were extremely stable throughout the range, the adenoviruses stable from $\mathrm{pH} 10$ to 3 , the myxoviruses from $\mathrm{pH} 10$ to about $\mathrm{pH}$ 5; the arthropod-borne viruses were stable only in very alkaline conditions.

Urea. Urea was tested because it is known to split hydrogen bonds and at concentrations between 0.5 and $4 \mathrm{M}$ a wide variety of responses was found. Some representative results are shown in Fig. 2. PVM virus and GD VII were unaffected by even the highest concentration though PVM was readily inactivated by acid. Myxoviruses were inactivated by urea concentrations of $3 \mathrm{M}$ or more; adenoviruses and enteroviruses by approximately half this concentration.

Bisulphite. The effect of a mild reducing agent was next studied. Sodium metabisulphite at $\mathbf{0} \cdot \mathbf{1 0 4} \mathrm{M}$ was convenient for a screening test; the myxoviruses, GD VII virus and the arthropod-borne viruses were sensitive, but the others were not. The most sensitive of the myxoviruses was influenza strain WS which was inactivated by one-eighth of the screening concentration whereas Sendai virus was affected by the screening concentration only.

Periodate. Treatment with periodate had an effect on all the viruses tested, but 
closely related viruses reacted differently; for example, ECHO 7 and SV 17 were little affected, but ECHO 12 and Adeno 7 were inactivated.

Sodium deoxycholate. Theiler (1957) showed that the infectivity of arthropodborne viruses was readily abolished by deoxycholate. We found complete inactivation of haemagglutinin in our tests with Semliki Forest and West Nile viruses, representatives of groups $\mathbf{A}$ and $\mathbf{B}$, respectively. No other haemagglutinin showed any change in titre after treatment.

Ether. Ether treatment also affected only the two arthropod-borne viruses, but the effect on Semliki Forest virus was weak and barely significant. Cheng (1961) found that treatment for a shorter time with two volumes of ether for two periods of $10 \mathrm{~min}$. at $3^{\circ}$ destroyed almost all the infectivity, but made no significant difference to the haemagglutinin of Semliki Forest virus.

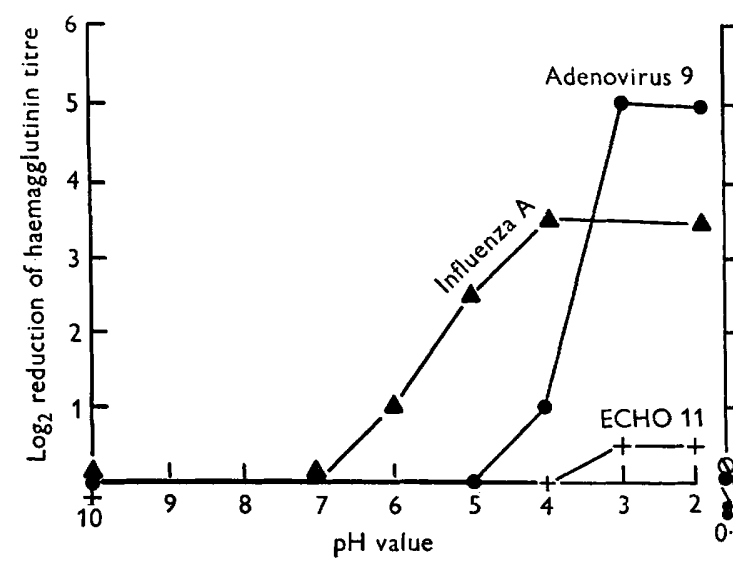

Fig. 1

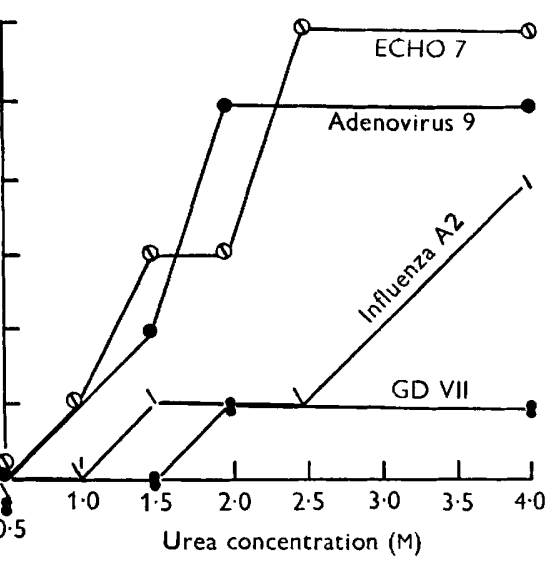

Fig. 2

Fig. 1. The effect on the haemagglutinin titre of exposure of certain viruses to various pH values. $-\mathbf{A}-$, influenza $\mathrm{A} ;---$, adenovirus 9 ; - - , ECHO 11.

Fig. 2. The effect on haemagglutinin titre of exposure to urea at various molarities $-Q-$, ECHO 7 ; - - - , adenovirus 9 ; - $\backslash$ - influenza A 2 ; - $\mathbf{8}-$, GD VII.

Proteolytic enzymes. Trypsin and chymotrypsin at $0.1 \mathrm{mg} . / \mathrm{ml}$. inactivated adenovirus type 9 only. Recently, however, Gresser \& Enders (1961), who used a higher concentration of trypsin $(0.5 \mathrm{mg}$. $/ \mathrm{ml}$.) and sampled periodically up to $48 \mathrm{hr}$., found that of the myxoviruses, mumps haemagglutinin was highly susceptible, Sendai relatively so and influenza $\mathrm{A}$ insusceptible. They considered that these findings might be of value in the classification of the group.

Papain attacked more viruses than did trypsin, but individual viruses were found to be susceptible or resistant in a way that bore no relationship to their broad biological groupings. REO virus type 2 , Iksha and the Lee viruses were inactivated by $0.1 \%$ papain, but WS, Mel and mumps were unaffected by $1 \%$.

Formalin (formaldehyde solution $40 \%, \mathrm{w} / \mathrm{v}$ ). Formalin is widely used at dilutions of less than $1 \%$ for inactivating virus infectivity, but the effect on the haemagglutinin of the high concentration used in these experiments varied from strain to strain. Some members of all virus groups were susceptible and myxoviruses were in general inactivated, but WS and Sendai were relatively resistant. Similarly, 
REO type 1 was susceptible although REO type 2 was not. Underwood \& Weed (1961) reported that glyoxal inactivated the infectivity of several viruses at a concentration that left that of poliomyelitis unimpaired. When we tested this compound on the haemagglutinin of some representative viruses it behaved like formalin, but was less active on a molecular basis.

Heat. All the viruses were heated at $56^{\circ}$ for 20,40 and $60 \mathrm{~min}$. as well as at $37^{\circ}$ for 1,3 and $16 \mathrm{hr}$. The $\mathrm{pH}$ value was kept at $\mathrm{pH} 9$ for arthropod-borne viruses, at $\mathrm{pH} 7 \cdot 2$ for other viruses; the viruses were suspended in serum-free medium or in PBS. All haemagglutinins but those of PVM and some myxoviruses were completely destroyed at the higher temperature in $20 \mathrm{~min}$., while at lower temperatures only arthropod-borne viruses, ECHO 11 and EMC, were decreased in titre. The effects of the higher temperature, together with that of periodate, bisulphite, papain and formalin are shown in Table 3.

Thiol reagents. The effect of $p$-chloromercuribenzoic acid on haemagglutinins has already been reported from this laboratory (Buckland, 1960) and by Philipson $\&$ Choppin (1960). Enteroviruses, REO, EMC and adenovirus type 7 were highly susceptible while the remainder were unaffected.

Table 3. $\log _{2}$ reduction in haemagglutinin $(H A)$ titre produced by indicated treatment of viruses

\begin{tabular}{|c|c|c|c|c|c|}
\hline & \multicolumn{5}{|c|}{ Treatment } \\
\hline & $\begin{array}{c}\text { Papain } \\
(1 \%)\end{array}$ & $\begin{array}{l}\text { formalin } \\
(20 \%) \\
\log \text { red }\end{array}$ & $\begin{array}{l}\text { bisulphite } \\
(0.104 \mathrm{M}) \\
\text { o in HA titre }\end{array}$ & $\begin{array}{l}\text { periodate } \\
(0.046 \mathrm{M})\end{array}$ & $\begin{array}{l}\text { heat } \\
56^{\circ} \text { for }\end{array}$ \\
\hline Virus & \multicolumn{4}{|c|}{$\log _{2}$ reduction in HA titre } & \\
\hline WS & 0.5 & 1.75 & 6 & 4.5 & 3 \\
\hline Mel & 0 & 5 & 6 & $4 \cdot 0$ & 1 \\
\hline A/Eng/59 & 3 & 6 & $3 \cdot 5$ & $2 \cdot 5$ & 2 \\
\hline Iksha & 5 & 3 & 4 & 4.5 & 4 \\
\hline Lee & 5 & $\mathbf{2 \cdot 3}$ & 4 & $4 \cdot 0$ & 2 \\
\hline Sendai & 2 & 2 & 5 & $6 \cdot 0$ & 5 \\
\hline Mumps & 0 & 4 & 2 & $2 \cdot 5$ & 2 \\
\hline REO 1 & 3 & $3 \cdot 5$ & 1 & 4 & 4 \\
\hline REO 2 & 3 & 0 & 1 & 3 & $\mathbf{5}$ \\
\hline ECHO 7 & 1.5 & $3 \cdot 6$ & $\mathbf{0}$ & $1 \cdot 5$ & 7 \\
\hline ECHO 11 & 0 & 3 & 0 & $2 \cdot 5$ & 5 \\
\hline ECHO 12 & 0 & 1 & 0 & $4 \cdot 6$ & 9 \\
\hline GD VII & 0 & 6 & 2 & 5 & $\mathbf{3}$ \\
\hline Adeno 7 & o & $6 \cdot 5$ & 0 & $5 \cdot 3$ & 7 \\
\hline Adeno 9 & 2 & 1 & 0 & $2 \cdot 25$ & 7 \\
\hline SV 17 & $0 \cdot 8$ & 1 & 1 & $1 \cdot 0$ & 5 \\
\hline EMC & 2 & 4 & 0 & 5 & 5 \\
\hline Columbia SK & 0.5 & $4 \cdot 5$ & $\mathbf{1}$ & $4 \cdot 3$ & 6 \\
\hline Semliki Forest & - & 4 & 4 & $4 \cdot 5$ & 5 \\
\hline West Nile & - & 5 & 6 & $6 \cdot 0$ & 5 \\
\hline PVM & 2 & - & $\mathbf{0}$ & $2 \cdot 75$ & 0 \\
\hline
\end{tabular}

Effect of various agents on red cell receptors

Formalin. Treatment of red cells with less than 1\% formalin produced little effect. At this concentration, however, there was no decrease or a slight increase of agglutinability with myxoviruses and arthropod-borne viruses, but a marked 
decrease on testing with ECHO, REO and adenoviruses; the decrease was somewhat less using EMC and Columbia SK. Some of these results have already been reported (Buckland, 1959).

Proteolytic enzymes. As it seemed that formalin might be acting on the amino groups of proteins, the effect of proteolytic enzymes was next tested. Philipson (1959) showed that chymotrypsin destroyed receptors for ECHO 11 virus; this was

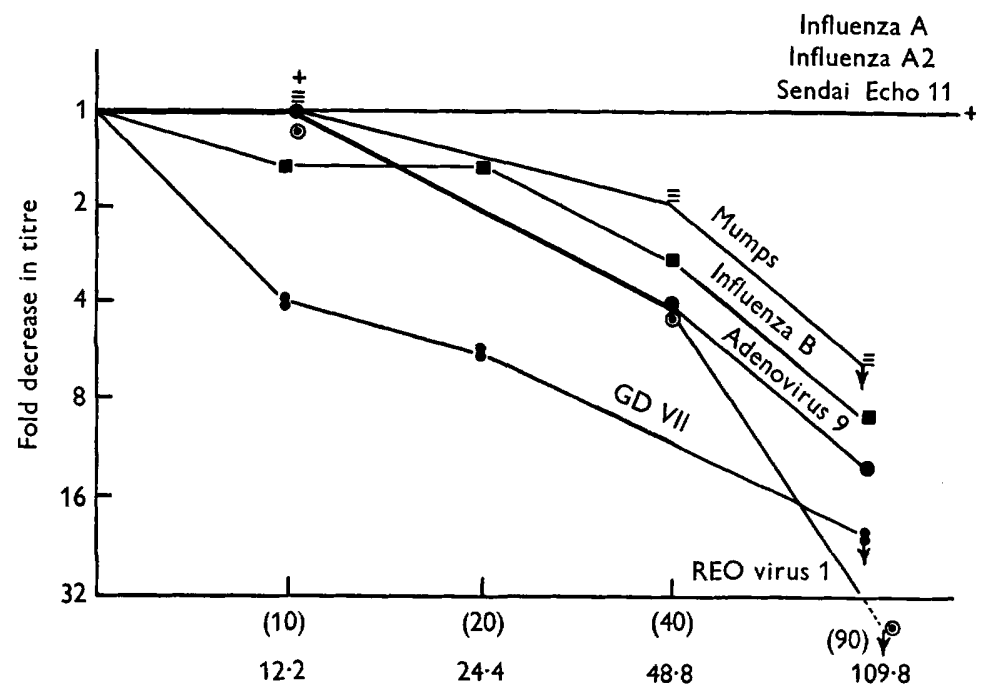

(a)

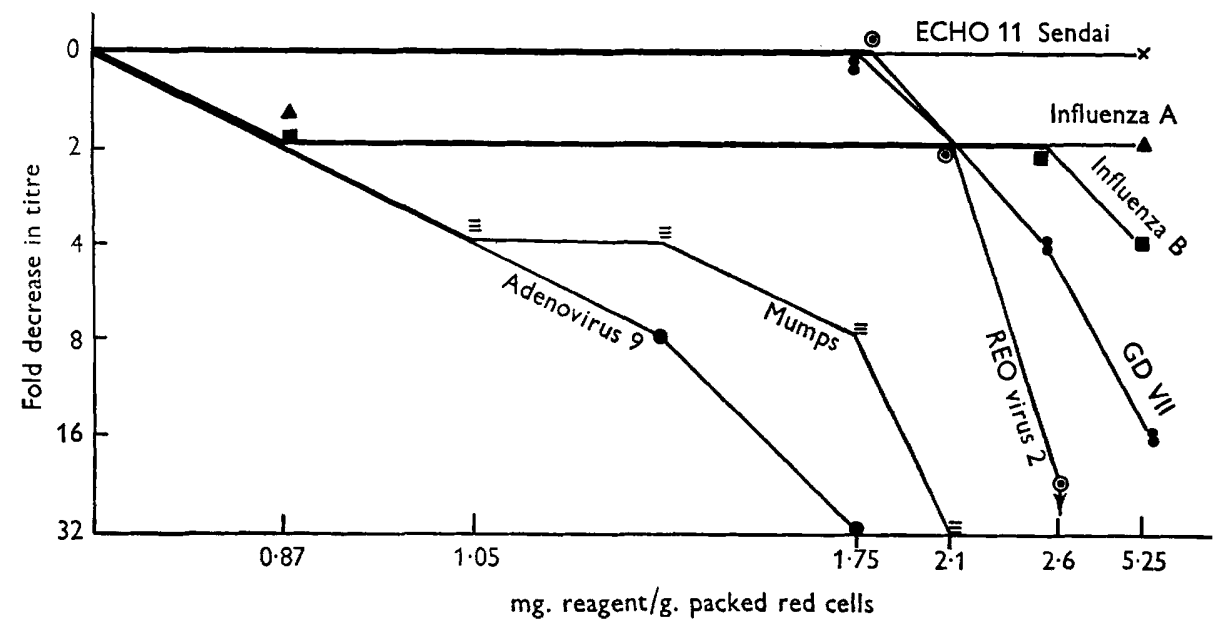

(b)

Fig. 3(a). Effect of increasing volumes of $0.0058 \mathrm{M}$-metaperiodate at ambient temperature $15^{\circ}$ to $20^{\circ}$. - - - influenza A, A2 Sendai, ECHO 11 ; - $\equiv-$, mumps; - - , influenza B ; - - - adenovirus 9 ; - - GD VII; - $-\square-$, REO virus 1 . 3(b). Effect of increasing concentration of reagent at ambient temperature of about $23^{\circ}\left(21-26^{\circ}\right)$. $-\times-$, ECHO 11, Sendai; - - , influenza $A$; - - , influenza $B$; - - - , GD VII; $-\odot-$, REO virus 2 ; - $\equiv-$, mumps; - - - adenovirus 9. 
confirmed, but it was found that, to a lesser extent, it also rendered cells inagglutinable by ECHO viruses types 7 and 12, REO viruses types 1 and 2 and adenovirus type 7 (Tables 3 and 5). Papain treatment prevented agglutination by more viruses than did treatment with chymotrypsin; agglutination by adenovirus type 9 and EMC virus was inhibited; agglutination by influenza A viruses was slightly decreased, but other myxoviruses and REO viruses were unaffected. The effectiveness of papain may be correlated with its powerful and relatively non-specific proteolytic activity. The slight effect of trypsin on agglutination by influenza $A$ (Hirst, 1948) was not observed, but different red cells and different virus strains were used.

Receptor destroying enzyme (neuraminidase): $R D E$. The receptor destroying enzyme (RDE) of cholera filtrate (Burnet \& Stone, 1947) has long been known to destroy receptors for influenza viruses and other myxoviruses (Andrewes et al. 1955). Our experiments confirmed this and also showed that the two A 2 strains we used behaved as ' + ' viruses, i.e. the receptors were not all destroyed by cholera filtrate (Takátsy \& Barb, 1959; Choppin \& Tamm, 1960). The receptors for adenoviruses were destroyed by RDE as was also observed by Kasel, Rowe \& Nemes, 1960. We confirmed that receptors for ECHO viruses are not inactivated by RDE (Goldfield, Srihongse \& Fox, 1957). As our experiments were done with a crude cholera filtrate preparation parallel tests were performed with an allantoic fluid containing swine influenza virus. The similarity in results suggested that the effect was due to RDE and not to any possible contaminating enzyme.

Oxidizing and reducing agents. Bisulphite at the concentration used had no effect on receptors. The destruction of receptors for influenza virus by periodate was reported by Hirst (1948) and Fazekas de St Groth (1949). A difficulty in extending these tests was the haemolytic effect of the higher concentrations of periodate used by these workers, but we found that this could be circumvented if the cells were treated with the same amount of periodate in a greater volume-the highest concentration used $(0 \cdot 0058 \mathrm{M})$ lay at the lower end of the range of concentrations which caused destruction of receptors for Mel; raising the concentration further in attempts to destroy all receptors resulted in haemolysis. The degree of receptor destruction was markedly affected by the exact conditions under which the test was carried out as can be seen by inspection of Figs. $3 a$ and $3 b$ and Table 4 . However, the general order of sensitivity was more or less the same whatever technique was used. The receptors for myxoviruses varied greatly in their sensitivity; Sendai virus receptors were completely resistant, while those of mumps were very sensitive. Adenovirus, GD VII and REO virus receptors were also very sensitive, but ECHO virus receptors were unaffected.

Agents which combine with -SH groups. Since $p$-chloromercuribenzoic acid had been found to inactivate certain virus haemagglutinins very effectively (Buckland, 1960) it was thought that this substance or iodoacetamide might act on red cell receptors. However, no inactivation was observed under the conditions used.

Experiments with sheep, rhesus monkey and goose red cells. Since certain viruses will agglutinate not only human red cells but those of some animals and birds, a limited number of experiments was carried out to see whether similar results were obtained when those cells were used instead of human ones. The reactions of treated human and sheep cells were similar (Table 5). The receptors for EMC and 


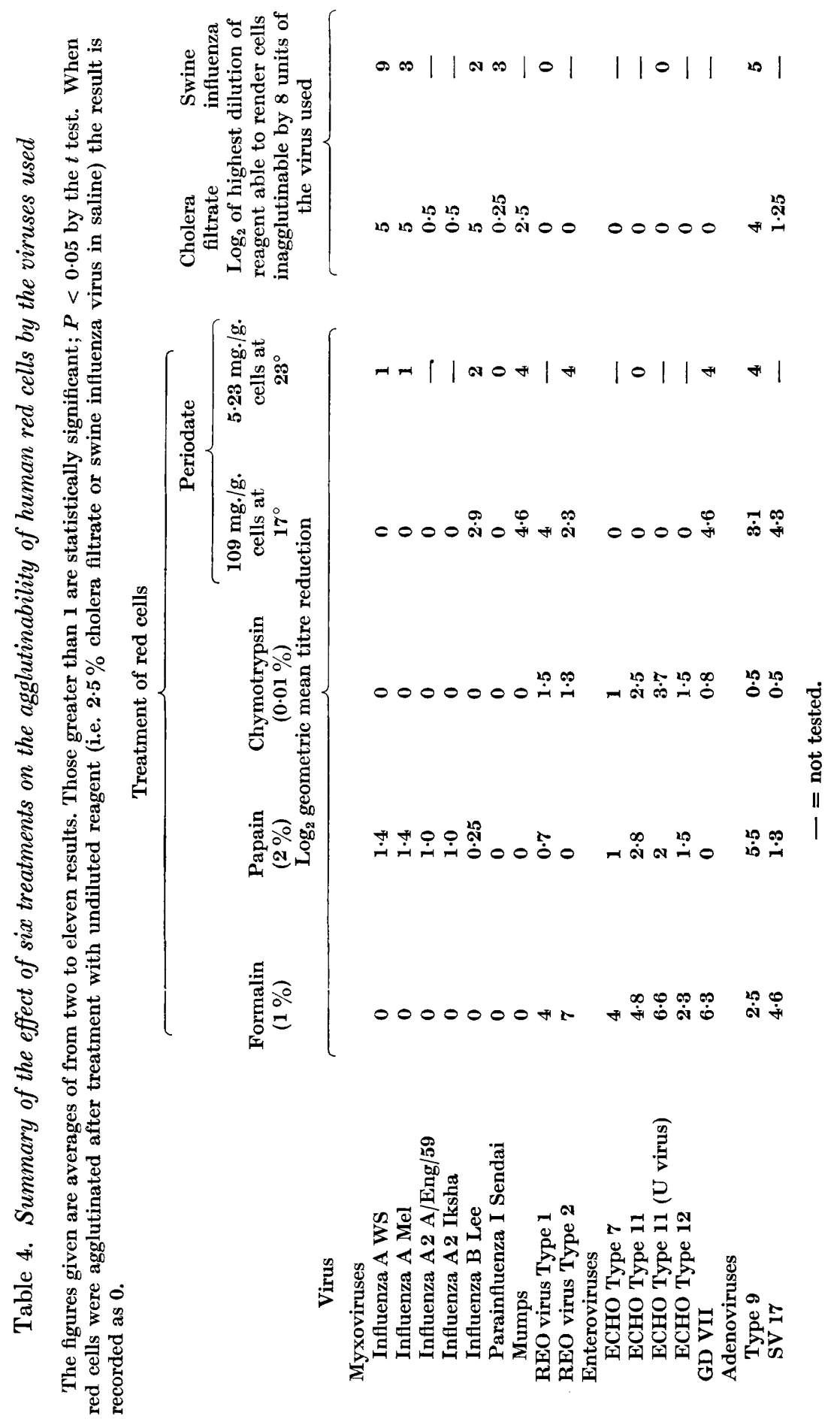




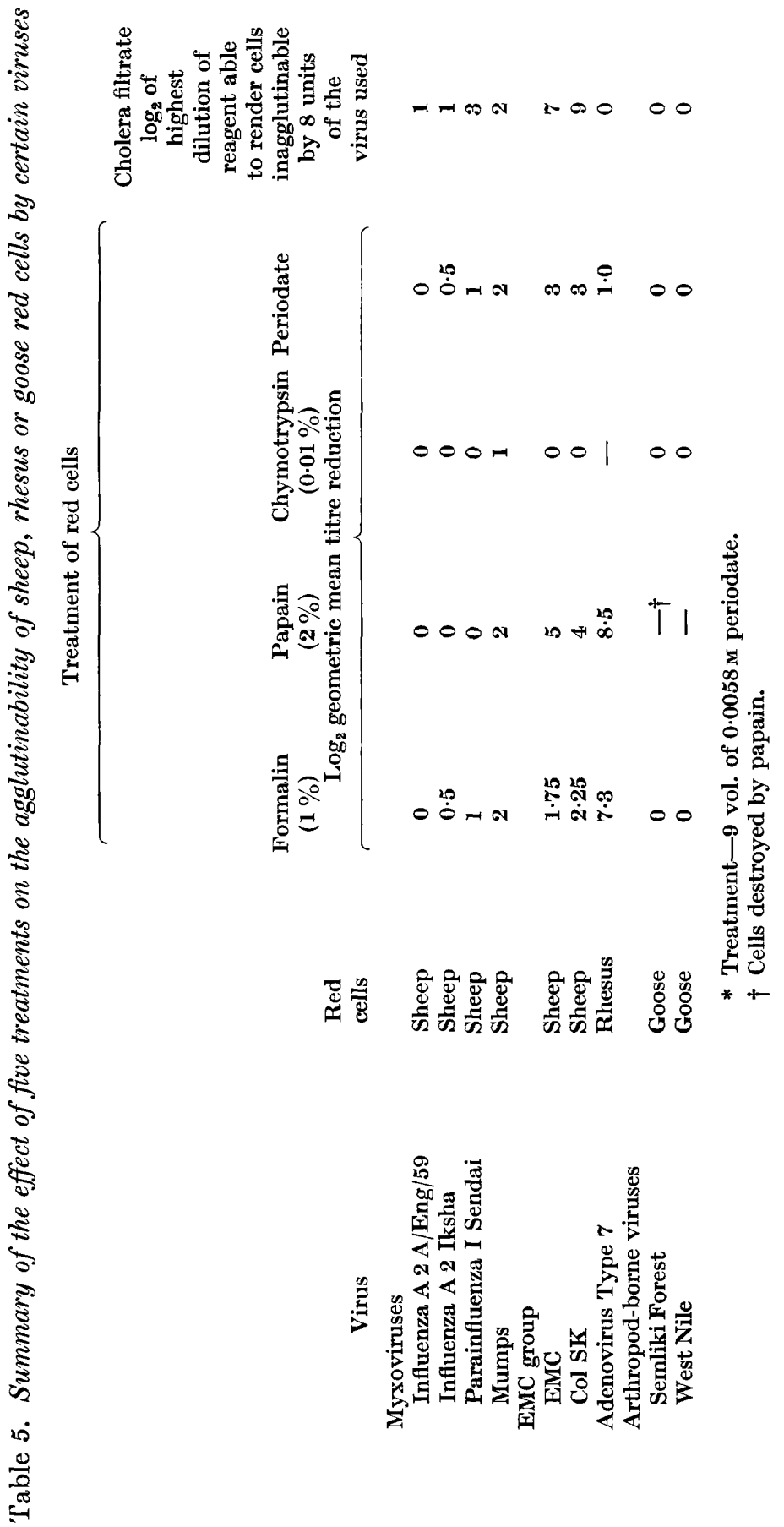


Columbia SK viruses were more readily destroyed than those for myxoviruses. On the other hand, the reaction of adenovirus 7 with treated rhesus red cells was slightly different from that of adenovirus 9 with human cells; adenovirus type 7 was able to agglutinate cells treated with periodate and cholera filtrate. This may have been due to differences in the virus or in the cells (see Table 5). It was also found that patas virus (SV 17) receptors on ox cells were not inactivated by formalin while receptors on human cells were inactivated. Treated goose cells, which reacted with influenza viruses like treated human cells, were agglutinated to full titre by the arthropod-borne viruses used. It was concluded that generally speaking, the results of treatment of red cells were not influenced by the species of red cell used.

Adsorption experiments. Red cells were treated with formalin, periodate, chymotrypsin and papain. The cell suspensions were then mixed with virus and the amount of haemagglutinin left in the supernatant fluid measured. In this way the capacity of treated red cells to absorb influenza WS and LEE, adenovirus type 9, REO virus types 1 and 2, ECHO viruses types 7, 11 and 12 and GD VII was measured. The results can be summarized by saying that treated cells which were agglutinable by the virus with which they were mixed could also absorb the virus; cells which were inagglutinable did not absorb virus. The only exception was that papain treated cells failed to absorb REO virus. It can, therefore, be concluded that in general the treatments which rendered red cells inagglutinable by specific viruses destroyed the receptors for that virus, just as in the classical work with RDE.

\section{DISCUSSION}

When the experimental work described in the paper was completed (1960) relatively little had been published on the in vitro behaviour or the haemagglutinins and receptors of viruses such as the adenoviruses and enteroviruses. Much more work has been published since then which confirms or goes beyond the facts reported here. However, this is the first publication of a systematic comparison of stability of a range of haemagglutinins on treatment with urea, different $\mathrm{pH}$ values, deoxycholate and bisulphite, of comparison of the effects on different virus receptors of proteolytic enzymes and periodate and the lack of effect of bisulphite on receptors of adeno, REO and ECHO viruses. A systematic comparison seemed desirable because differences in the source of viruses, the concentration of reagents or the time and temperature of the reaction may affect the results significantly. From the tables it can be seen that when the same techniques are used, the haemagglutinins of influenza WS and mumps were inactivated by periodate, the receptors for influenza WS were unaffected while those for mumps were destroyed. In contrast the haemagglutinin of REO virus type 1 was destroyed by formalin whereas that of REO virus type 2 was not, although the red cell receptors for both were destroyed.

The findings of these experiments suggest that there are chemical differences between the haemagglutinins in the main groups of viruses and in the red cell receptors for them and that certain subdivisions within a virus group based on a serological difference such as that found between influenza $\mathbf{A}$ and $\mathbf{B}$ have also a chemical difference which can be demonstrated by the use of papain. When an unknown virus isolated from Erythrocebus patas monkeys was investigated on 
these lines it was found to have a haemagglutinin resembling that of adenoviruses before it was shown to possess the adenovirus complement-fixing antigen (Tyrrell, Buckland, Lancaster \& Valentine, 1960) and it was finally identified as SV 17.

We are indebted to Dr H. G. Pereira for adenovirus type 7 suspensions, Drs T. H. Work and E. M. Martin for EMC preparations, Dr J. S. Porterfield for the arthropod-borne viruses, Dr A. C. Allison for the $p$-chloromercuribenzoic acid and iodoacetamide, and especially to Mrs P. K. Brown for technical assistance.

\section{REFERENCES}

Andrewes, C. H., Bang, F. B. \& Burnet, F. M. (1955). A short description of the myxovirus group (influenza and related viruses). Virology, 1, 176.

BUCKLAND, F. E. (1959). Impairment of viral haemagglutination of red cells after treatment with formalin. Nature, Lond. 183, 1276.

BUCKLAND, F. E. (1960). Inactivation of virus haemagglutinins by para-chloromercuribenzoic acid. Nature, Lond. 188, 768.

Burnet, F. M. \& Stone, Joyce D. (1947). The receptor destroying enzyme of $\boldsymbol{V}$. cholerae. Aust. J. exp. Biol. med. Sci. 25, 227.

Cheng, P-Y. (1961). Some physical properties of haemagglutinating and complementfixing particles of Semliki Forest virus. Virology, 14, 132.

Clarke, D. \& Casals, J. (1958). Techniques for haemagglutination and haemagglutination inhibition with arthropod-borne viruses. Amer. J. trop. Med. Hyg. 7, 561.

Choppin, P. W. \& Tamm, I. (1960). Studies of two kinds of virus particles which comprise $\mathrm{A}_{2}$ virus strains. J. exp. Med. 112, 895.

Fazekas de St Groth, S. (1949). Modification of virus receptors by metaperiodate. I. The properties of $\mathrm{IO}_{4}$-treated cells. Aust. J. exp. Biol. med. Sci. 27, 65.

Goldfield, M., Srinongse, S. \& Fox, J. P. (1957). Haemagglutinins associated with certain human enteric viruses. Proc. Soc. exp. Biol., N.Y. 96, 788.

Gresser, I. \& ENDERS, J. F. (1961). The effect of trypsin on representative myxoviruses. Virology, 13, 420.

Hirst, G. K. (1948). The nature of virus receptors of red cells. I. Evidence on the chemical nature of the virus receptors of red cells and of the existence of a closely analogous substance in normal serum. J. exp. Med. 87, 301.

KASEL, J. A., Rowe, W. P. \& Nemes, J. L. (1960). Modification of erythrocyte receptors by a factor in adenovirus suspension. Virology, 10, 388.

Martin, E. M., Malec, J., Sved, S. \& Work, T. S. (1961). Studies on protein and nucleic acid metabolism in virus infected mammalian cells. Part I. Assessment of a suitable system. Biochem. J. 80, 585.

Muschel, L. H. \& Piper, D. R. (1959). Enzyme treated red blood cells of sheep in the test for infectious mononucleosis. Amer. J. clin. Path. 32, 240.

Philipson, L. (1959). Studies on the mechanism of haemagglutination by Echo viruses. I. Evidence for enzymatic degradation by chymotrypsin of the receptor for Echo viruses. Arch. ges. Virusforsch. 9, 251.

Philipson, L. \& Choppin, P. W. (1960). On the role of virus sulphydryl groups in the attachment of enteroviruses to erythrocytes. J. exp. Med. 112, 455.

TAKÁtsy, G. \& BARB, K. (1959). New inhibitor and erythrocyte receptor substances for certain Asian strains of influenza virus. Nature, Lond. 183, 52.

Theiler, M. (1957). Action of sodium deoxycholate on arthropod-borne viruses. Proc. Soc. exp. Biol., N.Y. 96, 380.

Tyrrell, D. A. J., Buckland, F. E., Lancaster, M. C. \& Valentine, R. C. (1960). Some properties of a strain of SV 17 virus isolated from an epidemic of conjunctivitis and rhinorrhea in monkeys (Erythrocebus patas). Brit. J. exp. Path. 41, 610.

Underwoon, G. E. \& WeEd, S. D. (1961). The effect of carbonyl compounds on poliovirus. Virology, 13, 138. 